\title{
Transport and Attenuation of Salmonella enterica, Fecal Indicator Bacteria and a Poultry Litter Marker Gene are Correlated in Soil Columns
}

Running title: Attenuation of pathogens and FIB in soil columns

Sirisha Mantha, Civil and Environmental Engineering, West Virginia University

Angela Anderson, Civil and Environmental Engineering, West Virginia University

Saraswati Poudel Acharya, Civil and Environmental Engineering, University of Utah

Valerie J. Harwood, Department of Integrative Biology, University of South Florida

Jennifer Weidhaas *, Civil and Environmental Engineering, University of Utah, 110 Central

Campus Drive, Salt Lake City, UT 84112, P: 801-585-1228, E: jennifer.weidhaas@utah.edu

* corresponding author 


\section{ABSTRACT}

Millions of tons of fecal-contaminated poultry litter are applied to U.S. agricultural fields annually. Precipitation and irrigation facilitate transport of fecal-derived pathogens and fecal indicator bacteria (FIB) to groundwater. The goal of this study was to compare transport of pathogens, FIB, and a microbial source tracking marker gene for poultry litter (LA35) in a simulated soil-to-groundwater system. Nine laboratory soil columns containing four different soil types were used to evaluate microbial transport to groundwater via infiltration. Quantitative polymerase chain reaction was used to monitor Salmonella enterica Typhimurium, Escherichia coli, Enterococcus spp., Brevibacterium sp. LA35 and Bacteroidales leached from soil columns inoculated with poultry litter. S. enterica was correlated with LA35 poultry litter marker gene and FIB concentrations in column soils containing organic matter, but not in acid washed sands. In contrast, S. enterica was found to correlate with LA35 and FIB in the leachate from columns containing sand, but not with leachate from organic soil columns. The majority of recovered DNA was found in leachate of predominately sandy soil columns, and in the soil of loamy columns. At least $90 \%$ of the DNA retained in soils for each microbial target was found in the top $3 \mathrm{~cm}$ of the column. These studies suggest that poultry litter associated pathogens and FIB are rapidly released from litter, but are influenced by complex attenuation mechanisms during infiltration, including soil type. This study advances our understanding of the potential for subsurface transport of poultry litter associated pathogens and FIB, and support the use of the LA35 marker gene for evaluating poultry litter impacts on groundwater.

\section{KEYWORDS}

microbial source tracking; poultry litter; quantitative PCR; soil column studies; pathogens; fecal indicator bacteria; transport 


\section{INTRODUCTION}

An estimated 896,000 acres of US farmland in 2006 were fertilized with poultry litter (USDA, 2009). In total, 1.5 billion broiler chickens and 100 million turkeys were sold in the US in 2012 (USDA, 2014). Assuming $1.14 \mathrm{~kg}$ of litter produced per bird harvested (Tabler et al., 2009), approximately 1.7 billion $\mathrm{kg}$ of poultry litter (broiler chickens and turkey) was available for use as a fertilizer in 2012. Microorganisms, nutrients, sediments and metals can be released from the poultry litter applied as fertilizer during rainfall runoff (Brooks et al., 2009; Weidhaas et al., 2014) which then contaminates streams (Weidhaas and Lipscomb, 2013; Weidhaas et al., 2010) or infiltrates to groundwater potentially emerging in springs (Gooddy, 2002; Weidhaas et al., 2011).

Poultry litter harbors pathogens and fecal indicator bacteria such as Campylobacter sp. (Keramas et al., 2004), Clostridium perfringens (Brooks et al., 2009), enterococci, Escherichia coli, Salmonella sp., Staphylococcus sp., (Weidhaas et al., 2014) and viruses (Guan et al., 2009). These pathogens in land applied animal manure can migrate to groundwater during surface water or rainwater infiltration (Pachepsky et al., 2006; Weidhaas et al., 2014; Weidhaas et al., 2011). However complex fate and transport mechanisms affect pathogen migration during infiltration through the vadose zone. First, after surface application, microorganisms must survive exposure to environmental stressors (e.g., desiccation, UV light, nutrient scarcity) before the first rainfall or irrigation event. After microorganisms desorb from manure or litter during rainfall, rainwater volume must be sufficient to transport microorganisms through the macropores of the vadose zone to the saturated zone. If rainfall volume is insufficient or infiltration rates are too limited, microbes may be retained in micropores until sufficient infiltration water carries the microorganisms to groundwater. Factors shown to affect the transport of microorganisms 
through soils with infiltrating water include: soil grain size (Fontes et al., 1991) and soil particle surface properties (Sen, 2011), cell size and microbe surface properties (Gannon et al., 1991; Schinner et al., 2010), and soil water content. Finally, when present in the soil micropores or macropores, microorganisms may replicate or die (Wilkins et al., 2014), form biofilms or remain planktonic (Or et al., 2007).

Once microorganisms enter the saturated zone, their transport follows the general laws governing macropore flow and the interaction between soil and microbial surfaces of variable charges. Mechanisms shown to attenuate microbial transport in soils include: 1) macropore flow characteristics due to soil structure and porosity, 2) filtration effects in soil micropores, 3) adhesion or adsorption of microbial cells to soil minerals and organic particles (Unc and Goss, 2004). Despite these mechanisms to retard microbial movement in soils, microorganisms have been shown to be transported long distances [e.g., $456 \mathrm{~m}$ (Gerba et al., 1975)] depending on the soil type. However the abundance of microorganisms has been shown to be severely attenuated during transport with groundwater [e.g., 88\% removal (Pang et al., 2004)].

Several studies have evaluated pathogen transport during surface runoff from poultry litter amended fields (Brooks et al., 2009; Jenkins et al., 2006; Sistani et al., 2010; Sistani et al., 2009; Weidhaas et al., 2014), however very few studies have evaluated infiltration of microorganisms from poultry litter into soil pore water and groundwater (Gooddy, 2002; McMurry et al., 1998). Previous infiltration studies with poultry litter have shown $2 \cdot 10^{3}$ to 3 . $10^{5}$ fecal coliforms $\cdot(\mathrm{mL})^{-1}$ of fecal coliforms in leachate from $42.5 \mathrm{~cm}$ deep, intact soil blocks with $1 \cdot 10^{1}$ to $2 \cdot 10^{4}$ fecal coliforms $\cdot\left(\mathrm{g}_{\text {soil }}\right)^{-1}$ (McMurry et al., 1998). In these field studies the fecal coliforms leached as a pulse, but had variable areal abundance in the leachate from the bottom of the soil blocks, despite homogeneous application of poultry litter across the surface. In 
contrast, fecal coliforms, fecal enterococci, Salmonella spp., E. coli and Campylobacter spp. were not found in the $0.45 \mathrm{~m}$ deep chalk soils below turkey litter manure (Gooddy, 2002). To date, none of the previously published studies have systematically evaluated the mechanisms of microbial attenuation during transport of leachate from poultry litter applied as fertilizer.

Monitoring for pathogens in environmental samples has traditionally been dependent on indicator organisms such as fecal indicator bacteria (FIB). However, FIB such as E. coli and Enterococcus spp. are not specific to fecal sources such as poultry litter, rather they are associated with most warm blooded animal feces. Therefore various microorganisms been proposed to be used for monitoring environmental samples for impacts from chicken feces (Kobayashi et al., 2013; Lu et al., 2007) or poultry litter (Ryu et al., 2013; Weidhaas et al., 2010). Herein we propose to use the Brevibacterium sp. LA35 (hereafter LA35 marker gene), which has been shown to be highly concentrated in soiled poultry litter and rarely found in the feces of non-target animals (Ryu et al., 2013; Weidhaas et al., 2010).

Infiltration of pathogens originating from poultry litter applied as fertilizer to groundwater poses a potential risk to human health through exposure to these pathogens in water. The objective of this study was to evaluate the infiltration and attenuation of pathogens, FIB and a poultry litter marker gene originating from poultry litter. Specifically, studies were undertaken to determine if there was a correlation in the release, transport and attenuation of microorganisms originating from poultry litter through soil columns during simulated infiltration studies. Understanding of the attenuation of microorganisms in various soils will allow for better design of water quality monitoring programs and identification of the most appropriate microorganisms to quantify during sampling campaigns. By knowing which indicator organisms 
are transported similarly to pathogens in leachate or from groundwater seepage, one can more appropriately select monitoring methods, and better inform fate and transport models.

\section{MATERIALS AND METHODS}

2.1 Soil handling and characterization. Four soil types were used in nine column studies (Table 1). Sakrete natural play sand (Bonsal American, Inc. USA) was acid washed to remove organic material prior to its use. Briefly, the sand was sifted through $0.25 \mathrm{~mm}$ sieve (ASTM \#60) and then boiled in a 2-L conical flask containing $1 \mathrm{M}$ hydrochloric acid (Fischer Scientific, Pittsburgh, PA) for 2 hours. The sand was then rinsed with de-ionized water until the rinse water had a pH of 5.6 (Orion ROSS pH electrode, Thermo Scientific, Waltham, MA). The sand was then dried in an oven at $105^{\circ} \mathrm{C}$ overnight. The oven-dried sand was again re-rinsed in de-ionized water the following day and dried again overnight at $105^{\circ} \mathrm{C}$. The second soil type, a loamy sand was collected from the West Virginia University (WVU) Evansdale campus. A silt loam soil was collected from the WVU Organic Farm, while a loam soil was collected from the WVU downtown campus. All soils, excluding the sand were heated at $105^{\circ} \mathrm{C}$ overnight to remove moisture, then sterilized by autoclave prior to packing into the soil columns. DNA was extracted from autoclaved soils (ea. $0.25 \mathrm{~g}$ ) prior to setting up the soil column experiments to determine if any target microorganisms naturally present in the soils remained detectable by quantitative polymerase chain reaction (qPCR) after autoclaving. None of the target organisms were quantifiable by qPCR in the autoclaved soils (data not shown).

Soils were characterized by sieve analysis and by the pipette method as follows. First the sand and loamy sand were sieved through a $2 \mathrm{~mm}$ (ASTM \#10) sieve, then sand and loam sand grains that passed a $0.074 \mathrm{~mm}$ (ASTM \#200) sieve were considered clay and silt, the remainder was considered sand. Second, the silt loam and loam soils were sieved through a $0.595 \mathrm{~mm}$ sieve 
(ASTM \#30), and percent clay in the silt loam and loam soils was determined by the pipette method (Gee and Bauder, 1986; Kilmer and Alexander, 1949). Organic content for all soils (Table 1) was determined by weight loss via ignition at $360{ }^{\circ} \mathrm{C}$ (Ball, 1964).

2.2 Column construction. All materials used for the column construction (PVC column and tubing) were bleached with a $10 \%$ bleach solution prior to use. A total of nine soil columns were constructed: three loam and three silt loam columns, two loamy sand columns and one sand column. The nine soil columns each consisted of a $2 \mathrm{~cm}$ diameter PVC cylinder ranging in length from 12.5 to $15 \mathrm{~cm}$ long packed with a total of 12.6 to $13 \mathrm{~cm}$ of soil. The bottom of the PVC columns were closed using glass fiber wool (Fisher Scientific, Pittsburgh, PA) to retain soil while permitting the flow of water and microorganisms. The porosity of the soil columns (ratio of the volume of voids to total volume of the medium) was measured immediately before starting the flow through experiments by the water displacement method in a sterile graduated cylinder containing sterile de-ionized water. Specifically, the difference in water levels between the empty PVC column which was used for the soil column experiment and the packed soil column was used to estimate porosity. The packed soil columns were wetted from below and approximately 10 to 15 minutes was allowed to fill the pore space (volume of voids) with water until the top of the columns were damp, but not submerged. Columns were then drained by gravity flow.

Passage of a tracer (50 $\mathrm{mL}$ of $1 \mathrm{M} \mathrm{NaCl}$ in de-ionized water) through the previously saturated sand soil column, followed by $50 \mathrm{~mL}$ of de-ionized water was conducted to confirm the porosity estimation. Electrical conductivity in the column leachate was measured every 30 seconds using a conductivity meter (Hach conductivity meter, CO 150, USA). Electrical conductivity in the loam and silt loam column leachate was determined after sample collection 
using an ExStik II, multiparameter probe (pH/conductivity EC500, Extech Instruments, Nashua, New Hampshire). Electrical conductivity was not measured for the loamy sand columns.

2.3 Poultry litter collection and handling. The poultry litter samples were collected from the WVU Animal Sciences Farm (Morgantown, WV). Approximately six scoops (ca. $5 \mathrm{~g}$ each) of poultry litter were collected from random locations within a $2.1 \times 1.3 \mathrm{~m}^{2}$ area containing soiled poultry bedding (i.e., fecally contaminated wood shavings). Due to logistical constraints on the number of experimental columns that could be sampled simultaneously, soil columns were constructed and sampled on sequential dates, requiring multiple poultry litter collection events. Samples of soiled poultry litter for the sand study were taken from pens containing adult roosters, whereas the soiled poultry litter for the loamy sand studies were collected from pens containing female chickens aged 4 to 6 weeks (chicks). Poultry litter for the silt loam and loam soils were collected from pens of adult broiler hens. Sampling locations were biased towards wet litter to ensure sufficient quantities of microorganisms were present. The poultry litter was homogenized in the field in a sterile, stainless steel bowl by mixing with a sterile spoon. Loose feathers and large particles of wood shavings were removed. Homogenized samples of approximately $5 \mathrm{~g}$ were transferred into a sterile whirl pak bags (Nasco, Fort Atkinson, WI). Poultry litter samples were held on ice after collection and during transport to the laboratory. All litter samples were sieved upon receipt in the laboratory by shaking the litter through a sterile 2mm (ASTM \#10) sieve. All samples were held on ice for no longer than 3 hours prior to adding them to soil.

The invA gene of Salmonella enterica was not detectable by qPCR in the poultry litter collected for these studies in any of the three sampling events. Therefore, Salmonella enterica subspecies enterica serovar Typhimurium (ATCC 14028) was cultured in the lab and added to 
the litter prior to the initiation of the soil column studies as follows. S. enterica was enriched in 240 mL of selective RV-broth (Rappaport-Vassiliadis Oxoid, CMO669, Pittsburgh, PA) prepared according to manufacturer's instructions. For the sand and loamy sand columns, $S$. enterica was incubated at $37{ }^{\circ} \mathrm{C}$ at $200 \mathrm{rpm}$ (Fisher Scientific New Brunswick, NJ.) for 2 days or until the broth turned turbid, and then $240 \mathrm{~mL}$ of culture was concentrated by centrifugation (Avanti J-E, Beckman Coulter, USA) at 10,000 x g for 10 min at $17{ }^{\circ} \mathrm{C}$. Supernatant was removed by pipette and the pellet was aseptically added to $1.7 \mathrm{~g}$ of poultry litter in a sterile, stainless steel bowl and homogenized by mixing with a sterile spoon. For the silt loam and loam columns a total of $12.5 \mathrm{~mL}$ of overnight $S$. enterica culture (incubated as described above) was centrifuged at $10,000 \mathrm{x} \mathrm{g}$ for 5 minutes and the pellet was mixed into $1.5 \mathrm{~g}$ of poultry litter prior to adding it to the top of the columns. This S. enterica spiked poultry litter was immediately used in the soil column studies. The DNA from approximately $0.25 \mathrm{~g}$ of the spiked poultry litter was extracted for later qPCR analysis.

2.4 Column leachate and soil sampling. Immediately after wetting of the sand and loamy sand soil columns and determination of porosity, $1.7 \mathrm{~g}$ of homogenized poultry litter spiked with $S$. enterica was added to the top of the constructed columns. The columns were then connected to a peristaltic pump (Watson Marlow, Wilmington, MA) that delivered sterile de-ionized water at a rate of $16.4 \mathrm{~L} \mathrm{day}^{-1}$ to the top of the soil columns. One sample approximately every 0.5 to 1 pore volume of leachate through the soil columns was collected in sterile centrifuge bottles $(50 \mathrm{~mL})$. A total of 11 to 13 samples consisting of 30 to $40 \mathrm{~mL}$ of leachate were collected every 10 to 14 min. All the samples collected during the experiment were held on ice and were centrifuged (Avanti J-E, Beckman Coulter, USA) at $10,000 \mathrm{rpm}$ for $10 \mathrm{~min}$ at $17^{\circ} \mathrm{C}$ within two hours of collection. The supernatant was carefully discarded, retaining the cell and soil debris pellet. Then 
the tubes were washed with $0.5 \mathrm{~mL}$ of sterile $1 \mathrm{X}$ PBS to collect any DNA adsorbed on to the sides of the centrifuge tube. A total volume of $0.5 \mathrm{~mL}$ of cells and soil debris from the centrifuged sample suspended in 1X PBS was taken into DNA extraction.

For the silt loam and loam columns, after porosity was calculated, the soils were drained by gravity flow, wrapped in parafilm and stored overnight at $4{ }^{\circ} \mathrm{C}$. The following day, the columns were saturated from the bottom with sterile de-ionized water and then approximately $1.5 \mathrm{~g}$ of S. enterica spiked poultry litter was added to the top of soil column. De-ionized water was added by hand to the top of the silt loam and loam soil columns at a rate sufficient to ensure a relatively constant head of water on top of the litter. Leachate samples were collected in sterile centrifuge tubes $(50 \mathrm{~mL})$ until the electrical conductivity of the leachate decreased (Exstik II multiparameter probe), targeting collection every 0.5 to 1 pore volume of leachate. The silt loam soil column samples were collected every 10 minutes and the loam soil column samples were collected every 15 minutes. Ten samples from each column were filtered through a sterile 0.45 $\mu \mathrm{m}$ pore size, $47 \mathrm{~mm}$ nitrocellulose water testing membrane filter (Thermo Fisher Scientific, Inc, Waltham, MA). Filters were frozen at $-80^{\circ} \mathrm{C}$ and DNA was extracted from the shattered filters (Weidhaas and Lipscomb, 2013) as described below within one week of collection.

Soil columns were destructively sampled immediately after the cessation of gravity flow from the columns by removing the glass fiber wool and extruding the soil onto sterile aluminum foil. Sections were separated into 3 equal length layers from top to bottom. The three separate layers were homogenized independently using a sterile spatula and approximately $0.25 \mathrm{~g}$ of soil subsample was taken into the DNA extractions.

2.5 Nucleic acid extraction. Samples consisted of either 1) $0.5 \mathrm{ml}$ of centrifuged sample in $1 \mathrm{X}$ sterile PBS for the sand and loamy sand, 2) shattered water filters (Weidhaas and Lipscomb, 
2013) for the loam and silt loam or 3) $0.25 \mathrm{~g}$ of soil or poultry litter. The DNA from all the samples was extracted by a previously published method (Griffiths et al., 2000). Extracted DNA was placed into a lysing matrix E tube (MP Biomedicals, Solon, $\mathrm{OH}$ ). Concentration and quality of DNA were determined by absorbance at $260 \mathrm{~nm}$ with Nanodrop ND-1000 UV Spectrometer (Nanodrop Technologies, Wilmington, DE).

2.6 Quantitative PCR. Microbial abundance in leachate and soil samples was determined by qPCR targeting the invA gene of Salmonella enterica Typhimurium (Lee et al., 2006), the uidA gene of E. coli (Lee et al., 2006), the 23S rRNA gene of Enterococcus spp. (Ludwig and Schleifer, 2000), the 16S rRNA gene of the family Bacteroidales (Dick and Field, 2004; Siefring et al., 2008), and the 16S rRNA gene of the poultry litter associated Brevibacterium sp. LA35 (Weidhaas and Lipscomb, 2013) (Table 2). Each $25 \mu \mathrm{L} \mathrm{qPCR}$ reaction included $1 \mathrm{X}$ of the TaqMan® Fast Advanced Master Mix (Applied Biosystems, Carlsbad, CA, USA), previously published optimal primer (Integrated DNA Technologies, Inc., Coralville, IA) and probe concentrations (Biosearch Technologies, Inc, Novato, CA, USA), $1 \mu \mathrm{L}$ of extracted DNA, and molecular-grade water (Ambion, Carlsbad, CA, USA). All samples were run in triplicate. Amplification was performed using a 7300 Real Time PCR System (Applied Biosystems, Carlsbad, CA, USA) according to previously published methods (Table 2) with the exception of the master mix used. Control samples for each qPCR run included qPCR negative controls (e.g., DNA-free water instead of template), qPCR positive controls (e.g., marker gene inserted into a plasmid, linear DNA or DNA from pure cultures instead of template) and matrix spiked samples (i.e., plasmid or pure culture DNA added to DNA template). For construction of standard curves, a dilution series averaged approximately $10^{1}$ to $10^{7}$ target genomes containing LA35, Bacteroidales, E. coli, Enterococcus spp., and S. enterica target genes were assayed by qPCR. If 
the target gene was not detected via qPCR, the concentration of the gene was set at one half the minimum detection limit for statistical calculations (Weidhaas et al., 2010).

2.7 Statistical methods. Abundance of microbial gene targets and electrical conductivity from replicate columns were averaged by binning the data by pore volumes passing through the columns. The pore volume bins selected for averaging the data were in 0.5 pore volume increments. Pearson's correlations were determined using SigmaPlot (V 11.0, Systat Software, Inc., Chicago, IL, USA). Analysis of variance of the abundance of microorganism with depth in the soil columns was conducted using the PROC ANOVA subroutine of SAS (v. 9.4; SAS, Chicago, IL). Mass balances of microorganisms in the leachate was determined by multiplying the volume of water (L) in each incremental sample by the abundance of microbial genes per volume of water ( $\log$ gene copies $\left.\cdot \mathrm{L}^{-1}\right)$ and summing all incremental masses. Mass balances of microorganisms attached to the soil was determined by multiplying the mass of soil $(\mathrm{g})$ in each incremental sampling zone by the abundance of microbial genes per $\mathrm{g}$ of soil [log gene copies $\left.(\mathrm{g} \mathrm{soil})^{-1}\right]$ and summing all incremental soil depths. Total log gene copies of organisms in the applied liter were used to normalize the mass of genes in the leachate versus the soil. Abundance of microbial gene targets in the leachate were normalized (i.e., $\mathrm{C} / \mathrm{C}_{\mathrm{o}}$ ) by dividing the gene abundance $\cdot \mathrm{mL}^{-1}$ in any pore volume by the gene abundance $\cdot \mathrm{mL}^{-1}$ observed in the first sample collected. Average and standard deviation abundances of microorganisms in the first sample leachate samples collected from all soil columns were: $4.3 \pm 1.8$ (LA35), $4.7 \pm 3.4$ (Bacteroidales), $4.5 \pm 2.9$ (E. coli), $5.9 \pm 3.5$ (Enterococcus $\mathrm{spp}$ ), and $6.8 \pm 3.7$ (S. enterica) $\log$ gene copies $\cdot \mathrm{mL}^{-1}$.

\section{RESULTS}


Column pore volumes, packed bed porosities, and flow rates are presented in Table 1. Electrical conductivity in leachate from the soil columns over time indicates that there was minimal channeling in any column (Figure 1) as the tracer peak concentration leached from the columns at $1.1 \pm 0.3,1.8 \pm 0.5$, and $1.1 \pm 0.06$ pore volumes in the sand, silt loam and loam soils, respectively.

Initial abundance of microorganisms in the litter applied to the top of the soil columns is shown in Figure 2. The abundance of LA35 was highest in the litter of adult broilers and lower in chicks and roosters fed a specialized wheat-based food diet similar to that reported previously (Weidhaas and Lipscomb, 2013). In general Enterococcus spp. (9.9 \pm 1.0 log gene copies · $(\mathrm{g}$ litter) ${ }^{-1}$ ) were the most abundant in all litter samples followed by Bacteroidales, E. coli and LA35 $\left(8.5 \pm 0.6,7.6 \pm 0.5\right.$ and $7.2 \pm 1.6 \log$ gene copies $\cdot(\mathrm{g} \text { litter })^{-1}$, respectively). The abundance of the invA gene of $S$. enterica after spiking into the poultry litter was the highest of all the organisms, averaging $14.2 \pm 1.9 \log$ gene copies $\cdot(\mathrm{g} \text { litter })^{-1}$ for the sand and loamy sand soils and $8.5 \log$ gene copies $\cdot(\mathrm{g} \text { litter })^{-1}$ for the silt loam and loam soils.

Mass balance calculations were conducted to determine if the majority of the applied microorganism genes were released from the litter, transported through the columns (measured in column leachate) or accumulated in the soil profile (Figure 2). The mass percent microbial genes originating in litter recovered in either soil or leachate was $105 \pm 43 \%$ (Figure 2). Overall, a significantly greater mass percent of microbial genes across all organisms were recovered in the leachate from the predominately sandy soils (sand and loamy sand) than bound to the soil (Kruskal-Wallis One Way ANOVA on ranks, $P<0.001, \mathrm{n}=34$ ). The exception being LA35 mass percent recovery from sand soils was greater than that recovered in leachate. Conversely in the loamier soils (silt loam and loam), a greater mass percent (40 $\pm 26 \%$ ) of microbial genes 
across all organisms recovered from the soils than collected in the leachate $(25 \pm 9 \%)$ but not significantly (Kruskal-Wallis One Way ANOVA on ranks, $P=0.18, \mathrm{n}=55$ ). Detailed comparisons among microorganisms are shown below.

Peak abundance of all microorganisms in leachate from the acid washed sand column occurred at five pore volumes (Figure 1), which was significantly delayed compared to the $\mathrm{NaCl}$ tracer (peaking at 1.1 pore volumes). Acid washing of the sand column likely removed most organic material and functional groups from the silica, thus reducing potential chemical interactions between microbe cell wall structures and soil materials and producing sharplydefined peaks for the microorganisms. In contrast to the simultaneous detection of microorganisms in the leachate of the sand column, the loamy-sand columns had early arrival of low levels of Bacteroidales and LA35 (one to two pore volumes), and a later peak flush of all microorganisms at five pore volumes (Figure 1). Additional late peaks of LA35, Bacteroidales and E. coli after nine pore volumes occurred in the loamy-sand columns. Peak breakthrough of all microorganisms occurred between two and five pore volumes in the loam and silt loam soils.

In the leachate from all columns, the normalized abundance (i.e., C/Co) of the LA35 marker gene and the FIB over each pore volume were all significantly correlated with one another (Table 3) indicating similar transport rates through the soil. The only exception to this observation among the FIB was E. coli in the loam soil columns, which was not significantly correlated with Bacteroidales or enterococci. However, only in the leachate from the sand column was the abundance of S. enterica correlated with the other organisms monitored.

The abundance of microorganisms in all soil types (Figure 3) decreased significantly with depth (ANOVA least significant difference, $\mathrm{n}=180, P=0.05$ ). Abundance of all microorganisms decreased $5.3 \pm 1.7 \log$ gene copies $\cdot(\mathrm{g} \text { soil })^{-1}$ over the total $12 \mathrm{~cm}$ of all soil 
columns. Bacteroidales abundance decreased the least $\left(4.3 \pm 1.5 \log\right.$ gene copies $\left.\cdot(\mathrm{g} \text { soil })^{-1}\right)$ over the $12 \mathrm{~cm}$ of all the soil columns, but not significantly differently than the other organisms (ANOVA, $P=0.5$ ). Microorganism abundance in the $12 \mathrm{~cm}$ of the loam column decreased the greatest $\left(6.3 \pm 0.6 \log\right.$ gene copies $\left.\cdot(\mathrm{g} \text { soil })^{-1}\right)$, but not significantly more than other soils tested (ANOVA, $P=0.09$ ).

Abundance of organism genes with soil depth were correlated (Pearson's Product Moment, $P<0.05$ ) with one another, with a few exceptions (Table 4). Abundance of all organisms attached to soils with depth were correlated in the loamy sand columns, except for LA35 and E. coli $(P=0.19)$. Correlation of the abundance of microorganisms attached to the sandy soil with depth were only observed between LA35 and Enterococcus spp., Bacteroidales and Enterococcus spp., and between E. coli and Bacteroidales. S. enterica was correlated with LA35 marker gene and the FIB in the silt loam and loam soil columns.

A total of $133 \pm 76 \%$ of LA35 genes (DNA) applied in the poultry litter were recovered in the leachate and soils of the nine column studies. Similarly, $114 \pm 25 \%$ of Bacteroidales, $94 \pm$ $47 \%$ of E. coli, $92 \pm 33 \%$ of Enterococcus spp. and $89 \pm 21 \%$ of S. enterica gene copies were recovered in the leachate and soils of the five column studies. There was no significant difference (ANOVA, $P=0.60$ ) in the total mass of microbial genes recovered from all soil depths and leachate for any of the microbial genes assayed. Additionally, the mass of microorganisms on the soils did vary between replicate treatments. This variability was likely due to soil sampling bias during soil homogenization and collection for DNA extraction rather than variability in soils in replicate treatments.

\section{DISCUSSION}


Design of environmental monitoring plans requires an understanding of expected transport of microorganisms from agricultural and other sources. For example, an understanding of how soil type influences microbial transport with infiltrating rainwater would aid in assessing how deep to sample in agricultural soils. Further, if microbes are typically not expected to adhere to soil particles due to the soil properties (e.g., sandy soils lacking functional groups) efforts can be focused on groundwater or soil field tile seepage sampling.

Mass balance estimates in this study indicate that the transport of microorganisms from the applied poultry litter depended upon the soil type, i.e. more DNA was recovered in the leachate of sandy soil columns, and in the soil of loamy columns. The acid washed sand soils used in these studies lacked organic functional groups which have been previously shown to retard the movement of bacteria through porous media due to interactions between bacterial surface chemistry and soil functional groups (Scholl and Harvey, 1992). Further, multiple breakthrough peaks were observed in the loamy sand and silt loam soil columns but not in the acid washed sand columns. Others have reported similar multi-phased transport patterns. For example, E. coli and C. parvum oocysts were shown to have multiple peaks in the leachate from intact soil cores under simulated rainfall conditions (Forslund et al., 2011; Harter et al., 1999). Potential reasons for multiple peak microbial abundances include 1) variations in transport rates of free nucleic acids versus intact cells, 2) heterogeneity in the soil column material, 3) soil and microorganism cell wall interactions, 4) variable advection rates due to water pressure fluctuations and 5) preferential transport of microorganisms along the walls of the column. Free nucleic acids, such as antibiotic resistance genes, have been shown to survive outside of a cell for 3 to 10 hours (Demanèche et al., 2001; Poté et al., 2003) in soil columns, and may travel as fast as conservative tracers (Poté et al., 2003). 
In the leachate from the loamy sand columns in this study, multiple peak concentrations of microorganisms were observed (Figure 1). Soil columns that contain heterogeneities, such as a vein of coarse sand through a bed of finer sand, have been shown to generate double peak breakthrough curves (Fontes et al., 1991). For example, early peaks of microorganisms in the leachate time series could be due to microorganisms transported through a course-grained vein, while the later peaks are dominated by cells which have moved via dispersion through the finergrained matrix. In these studies, we sieved the soils prior to packing the columns to limit heterogeneity of the soil material. An alternative theory to multiple peaks in the loamy sand column leachate could be that free nucleic acids or starved cells with smaller diameters arrived early in the breakthrough curve, while the later peak was due to transport of intact microorganisms undergoing straining and reversible adhesion to the soil. However, to definitively prove free nucleic acid transport, the qPCR method would have to be combined with propidium or ethidium monoazide (PMA or EMA, respectively) to inhibit PCR amplification of free nucleic acids and non-viable cells.

In some cases in these studies, more than $100 \%$ of the microorganisms (in terms of DNA) applied in the litter were recovered in the leachate and soils based on mass balance estimates. Reasons for greater than $100 \%$ recovery of microorganisms in the mass balances include: 1) growth of the microorganisms during the studies, and 2) heterogeneity of microbial distribution the poultry litter, which was initially sampled to determine the original mass of microorganisms applied. Others have shown that growth of microorganisms in soil after release from manure may occur (e.g., E. coli O157:H7 strain B6914 from dairy cattle manure and/or soils over 8-hours (Gagliardi and Karns, 2000)), representing a long term source of pathogens in agricultural soils. Fecal indicator bacteria may also multiply in extra-intestinal environments (i.e., Bacteroidales 
from poultry litter increased $4 \log$ gene copies $\cdot(\mathrm{mL})^{-1}$ over 48 hours (Weidhaas et al., 2015)). However, growth of the microorganisms after release from the poultry litter in these studies is unlikely as the experiment was conducted over 1 to 3 hours. It is more likely that heterogeneity in the litter sample applied to the soil columns accounted for the discrepancy in the mass balance estimate. Since poultry litter typically consists of soil, bedding material (e.g., wood shavings, straw), feces, feathers and feed, it is difficult to get a homogeneous, representative sample for DNA extraction. This heterogeneity could result in either an over or underestimation of the mass of microorganisms attached to litter. Therefore, the mass balance estimates should be used as relative estimates of the mass of microorganisms on soils or in the leachate, rather than absolute values. The greater degree of homogenization possible with the sieved soil samples collected during soil column deconstruction ensured that the soil sample DNA concentrations observed are representative of absolute microbial abundances.

The magnitude of microorganism retention in soils due to straining and physicalchemical filtration has been shown to be a function of the ratio of the diameter of the microorganisms or colloids to the diameter of the collector or media (Xu et al., 2006). Porous media with pores larger than the diameter of the cells primarily retain microorganisms through reversible adsorption (e.g., electrostatic or van der Waals forces (Mozes et al., 1987)) and adhesion which is thought to be irreversible adsorption. These attenuation mechanisms will serve to dampen the peak abundance of microorganisms and delay their transport through the porous media. We observed a 2.2 to $8.2 \mathrm{log}$ decline in microorganism gene copies $\cdot(\mathrm{g} \text { soil })^{-1}$ in these studies over the $12 \mathrm{~cm}$ columns, with the greatest reductions observed for Salmonella and the least for Bacteroidales (Figure 3). Others have reported that E. coli O157:H7 and S. enterica Typhimurium applied as dairy cattle manure or fecal slurry both decreased 2 to $4 \log \mathrm{CFU} \cdot(\mathrm{g}$ 
dry weight of soil) $)^{-1}$ over $40 \mathrm{~cm}$ of sandy soil with 24 hours of simulated rainfall (Semenov et al., 2009). Our results and others are in contrast to those for Cryptosporidium parvum oocysts, where there oosyst abundance in loamy-sand soil declined only one log over $20 \mathrm{~cm}$ (Petersen et al., 2012). Similarly, Boyer et al (2009) reported a decline in C. parvum from 1.5 to 0.1 oocysts $\cdot(\mathrm{g}$

soil) $^{-1}$ over $50 \mathrm{~cm}$ of silt loam soil (Boyer et al., 2009). These results are surprising given the average diameter of $C$. parvum oocysts is approximately 5 um, or 5 to 10 times that of most bacterial cells (Harter et al., 1999).

In these studies, the pathogen $S$. enterica, the poultry litter marker LA35, and the FIB were found to correlate with one another in the leachate from the sand column. In contrast in the loamy sand column, only LA35 and the FIB were found to be correlated. Therefore, microorganism transport is likely to be highly variable through soils where greater interactions between the microorganism's cell structure and soil organic matter is likely to occur.

\section{CONCLUSIONS}

- The soil column studies provide evidence that pathogens and FIB will be rapidly released from poultry litter during rainfall and irrigation events.

- S. enterica was correlated with LA35 poultry litter marker gene and FIB in soils containing organic matter, but not in acid washed sands, and

- Sorption and physical filtration effects reduced the abundance of microorganisms in the leachate from $12 \mathrm{~cm}$ of soil columns between 2 to $9 \log$ gene copies ( $\mathrm{g}$ soil $)^{-1}$.

\section{ACKNOWLEDGEMENTS}

Funding for this project was partially obtained from a Summer Undergraduate Research Fellowship from the WVU Department of Civil and Environmental Engineering, as well as 
National Science Foundation (NSF) Environmental Engineering program funding to Jennifer Weidhaas (Grant no. 1234366). 


\section{REFERENCES}

Ball D. Loss-on-ignition as an estimate of organic matter and organic carbon in non-calcareous soils. Journal of Soil Science 1964; 15: 84-92.

Boyer D, Kuczynska E, Fayer R. Transport, fate, and infectivity of Cryptosporidium parvum oocysts released from manure and leached through macroporous soil. Environmental Geology 2009; 58 1011-1019.

Brooks JP, Adeli A, Read JJ, McLaughlin MR. Rainfall simulation in greenhouse microcosms to assess bacterial-associated runoff from land-applied poultry litter. Journal of Environmental Quality 2009; 38: 218-229.

Demanèche S, Jocteur-Monrozier L, Quiquampoix H, Simonet P. Evaluation of Biological and Physical Protection against Nuclease Degradation of Clay-Bound Plasmid DNA. Applied and Environmental Microbiology 2001; 67: 293-299.

Dick L, Field K. Rapid estimation of numbers of fecal Bacteroidetes by use of a quantitative PCR assay for 16S rRNA genes. Applied and Environmental Microbiology 2004; 70: 5695-5697.

Fontes D, Mills A, Hornberger G, Herman J. Pysical and chemical factors influencing transport of microorganisms through porous media. Applied and Environmental Microbiology 1991; 57: $2473-2481$.

Forslund A, Markussen B, Toenner-Klank L, Bech TB, Jacobsen OS, Dalsgaard A. Leaching of Cryptosporidium parvum Oocysts, Escherichia coli, and a Salmonella enterica Serovar Typhimurium Bacteriophage through Intact Soil Cores following Surface Application and Injection of Slurry. Applied and Environmental Microbiology 2011; 77: 8129-8138.

Gagliardi JV, Karns JS. Leaching of Escherichia coli 0157:H7 in Diverse Soils under Various Agricultural Management Practices. Applied and Environmental Microbiology 2000; 66: 877-883. 
Gannon J, Manilal V, Alexander M. Relationship between cell surface properties and transport of bacteria through soil. Applied and Environmental Microbiology 1991; 51: 190-193.

Gee G, Bauder J. Particle size analysis. In: Klute A, editor. Methods of Soil Analysis, Part 1. Physical and Mineralogical Methods. Agronomy Monograph No. 9. American Society of Agronomy/Soil Science Society of America, Madison, WI, 1986, pp. 383-411.

Gerba CP, Melnick J, Wallis C. Fate of wastewater bacteria and viruses in soil. Journal of the Irrigation and Drainage Division 1975; 101: 157-174.

Gooddy DC. Movement of leachate from beneath turkey litter sited over chalk in southern England. Journal of Environmental Science and Health, Part B 2002; 37: 81-91.

Griffiths R, Whiteley A, O'Donnell A, Bailey M. Rapid method for coextraction of DNA and RNA from natural environments for analysis of ribosomal DNA and rRNA-based microbial community composition. Applied and Environmental Microbiology 2000; 66: 5488-5491.

Guan J, Chan M, Grenier C, Wilkie DC, Brooks BW, Spencer JL. Survival of Avian Influenza and Newcastle Disease Viruses in Compost and at Ambient Temperatures Based on Virus Isolation and RealTime Reverse Transcriptase PCR. Avian Diseases 2009; 53: 26-33.

Harter T, Wagner S, Atwill ER. Colloid Transport and Filtration of Cryptosporidium parvum in Sandy Soils and Aquifer Sediments. Environmental Science \& Technology 1999; 34: 62-70.

Jenkins MB, Endale DM, Schomberg HH, Sharpe RR. Fecal bacteria and sex hormones in soil and runoff from cropped watersheds amended with poultry litter. Science of the Total Environment 2006; 358: 164-177.

Keramas G, Bang D, Lund M, Madsen M, Bunkenborg H, Telleman P, et al. Use of culture, PCR analysis, and DNA microarrays for detection of Campylobacter jejuni and Campylobacter coli from chicken feces. Journal of Clinical Microbiology 2004; 42: 3985-3991.

Kilmer V, Alexander L. Methods of making mechanical analyses of soils. Soil Science 1949; 68: 15-24. 
Kobayashi A, Sano D, Hatori J, Ishii S, Okabe S. Chicken- and duck-associated Bacteroides-Prevotella genetic markers for detecting fecal contamination in environmental water. Applied Microbiology and Biotechnology 2013; 97: 7427-7437.

Lee D-Y, Shannon K, Beaudette LA. Detection of bacterial pathogens in municipal wastewater using an oligonucleotide microarray and real-time quantitative PCR. Journal of Microbiological Methods 2006; 65: 453-467.

Lu J, Domingo J, Shanks O. Identification of a chicken-specific fecal microbial sequences using a metagenomic approach. Water Research 2007; 41: 3561-3574.

Ludwig W, Schleifer K. How quantitative is quantitative PCR with respect to cell counts? Systematic and Applied Microbiology 2000; 23: 556-562.

McMurry S, Coyne M, Perfect E. Fecal coliform transport through intact soil blocks amended with poultry manure. Journal of Environmental Quality 1998; 27: 86-92.

Mozes N, Marchal F, Hermesse MP, Van Haecht JL, Reuliaux L, Leonard AJ, et al. Immobilization of microorganisms by adhesion: interplay of electrostatic and nonelectrostatic interactions. Biotechnol Bioeng 1987; 30: 439-50.

Or D, Smets BF, Wraith JM, Dechesne A, Friedman SP. Physical constraints affecting bacterial habitats and activity in unsaturated porous media - a review. Advances in Water Resources 2007; 30: $1505-1527$.

Pachepsky YA, Sadeghi AM, Bradford SA, Shelton DR, Guber AK, Dao T. Transport and fate of manureborne pathogens: Modeling perspective. Agricultural Water Management 2006; 86: 81-92.

Pang L, Close M, Goltz M, Sinton L, Davies H, Hall C, et al. Estimation of septic tank setback distances based on transport of E. coli and F-RNA phages. Environment International 2004; 29: 907-921. 
Petersen H, Enemark H, Olsen A, Mostofa Amin M, Dalsgaard A. Transport of Cryptosporidium parvum oocysts in soil columns following applications of raw and separated liquid slurries. Applied and Environmental Microbiology 2012; 78: 5994-6000.

Poté J, Ceccherini MT, Van VT, Rosselli W, Wildi W, Simonet P, et al. Fate and transport of antibiotic resistance genes in saturated soil columns. European Journal of Soil Biology 2003; 39: 65-71.

Ryu H, Elk M, Khan IUH, Harwood VJ, Molina M, Edge T, et al. Comparison of two poultry litter qPCR assays targeting the 16S rRNA gene of Brevibacterium sp. Water Research 2013; 48: 613-621.

Schinner T, Letzner A, Liedtke S, Castro FD, Eydelnant IA, Tufenkji N. Transport of selected bacterial pathogens in agricultural soil and quartz sand. Water Research 2010; 44: 1182-1192.

Scholl MA, Harvey RW. Laboratory investigations on the role of sediment surface and groundwater chemistry in transport of bacteria through a contaminated sandy aquifer. Environmental Science \& Technology 1992; 26: 1410-1417.

Semenov AV, van Overbeek L, van Bruggen AHC. Percolation and Survival of Escherichia coli 0157:H7 and Salmonella enterica Serovar Typhimurium in Soil Amended with Contaminated Dairy Manure or Slurry. Applied and Environmental Microbiology 2009; 75: 3206-3215.

Sen T. Processes in Pathogenic Biocolloidal Contaminants Transport in Saturated and Unsaturated Porous Media: A Review. Water, Air, \& Soil Pollution 2011; 216: 239-256.

Siefring S, Varma M, Atikovic E, Haugland R. Improved real-time PCR assays for the detection of fecal indicator bacteria in surface waters with different instrument and reagent systems. Journal of Water and Health 2008; 6: 225-237.

Sistani K, Bolster C, Way T, Tobert H, Pote D, Watts D. Influence of Poultry Litter Application Methods on the Longevity of Nutrient and E. coli in Runoff from Tall Fescue Pasture. Water, Air, \& Soil Pollution 2010; 206: 3-12. 
Sistani K, Torbert H, Way T, Bolster C, Pote D, Warren J. Broiler Litter Application Method and Runoff Timing Effects on Nutrient and Escherichia coli Losses from Tall Fescue Pasture. Journal of Environmental Quality 2009; 38: 1216-1223.

Tabler G, Liang Y, Van Devender K. Poultry litter production and associated challenges. Avian Advice. 11. University of Arkansas, Division of Agriculture, Cooperative Extension Service, 2009, pp. 8-10.

Unc A, Goss MJ. Transport of bacteria from manure and protection of water resources. Applied Soil Ecology 2004; 25: 1-18.

USDA. Manure use for fertilizer and energy: Report to Congress. United States Department of Agriculture, June, 2009.

USDA. 2012 Census of Agriculture, United States Department of Agriculture, AC-12-A-51, May, 2014.

Weidhaas J, Garner E, Basden T, Harwood VJ. Runoff studies demonstrate parallel transport behavior for a marker of poultry fecal contamination and Staphylococcus aureus. Journal of Applied Microbiology 2014; 117: 417-429.

Weidhaas J, Lipscomb E. A new method for tracking poultry litter in the Potomac Basin headwaters of West Virginia. Journal of Applied Microbiology 2013; 115: 445-454.

Weidhaas J, Macbeth T, Olsen R, Harwood V. Correlation of Quantitative PCR for a Poultry-Specific Brevibacterium Marker Gene with Bacterial and Chemical Indicators of Water Pollution in a Watershed Impacted by Land Application of Poultry Litter. Applied and Environmental Microbiology 2011; 77: 2094-2102.

Weidhaas J, Macbeth T, Olsen R, Sadowsky M, Norat D, Harwood V. Identification of a Brevibacterium marker gene specific to poultry litter and development of a quantitative PCR assay. Journal of Applied Microbiology 2010; 309: 334-347. 
Weidhaas J, Mantha S, Hair E, Nayak B, Harwood VJ. Evidence for extra-intestinal growth of Bacteroidales originating from poultry litter. Applied and Environmental Microbiology 2015; 81: 196-202.

Wilkins MJ, Kennedy DW, Castelle CJ, Field EK, Stepanauskas R, Fredrickson JK, et al. Single-cell genomics reveals metabolic strategies for microbial growth and survival in an oligotrophic aquifer. Microbiology 2014; 160: 362-372.

Xu S, Gao B, Saiers JE. Straining of colloidal particles in saturated porous media. Water Resources Research 2006; 42: W12S16. 


\section{LIST OF TABLES}

Table 1. Soil and column properties of the differing soil types used during this study.

Table 2. qPCR primers and probes used in this study.

Table 3. Within-column relationships of microbial transport with leachate: Pearson's correlation of normalized ${ }^{\mathrm{a}}$ gene abundance of the various microorganisms in leachate from soil columns in each pore volume sampled. Sand and silt loam with white background; loam sand and loam with gray background.

Table 4. Within-column relationships of microbial abundance with depth in soils: Pearson's correlation of log microbial gene abundance of the various microorganisms attached to soil columns over all depths sampled. Sand and silt loam with white background; loam sand and loam with gray background. 


\section{LIST OF FIGURES}

Figure 1. Relative change in abundance of target genes and chloride tracer in leachate from soil columns. Symbols represent the average and standard deviation from replicate treatments (excluding sand column) by the binned pore volumes. Bars represent the average and standard deviation in leachate flow rate from the soil columns.

Figure 2. Average abundance of target genes (symbols) in the poultry litter added to the soil columns and the mass percent gene copies recovered from the soil (grey bars) or column leachate (white bars). Error bars represent the standard deviation of duplicate (loamy sand) or triplicate (loam and silt loam) columns.

Figure 3. Abundance of target genes with depth in the soil columns. Bar graphs represent $50 \%$ of the data, the horizontal line within the box represents the median. Symbols represent observed gene abundance in each of the soil columns. Means of the bar graphs with a different letter (lower case) have significantly different abundance with depth $(P=0.05$, ANOVA, least significant difference). The vertical dashed line represents one half the minimum detection limit. 
Figure 1
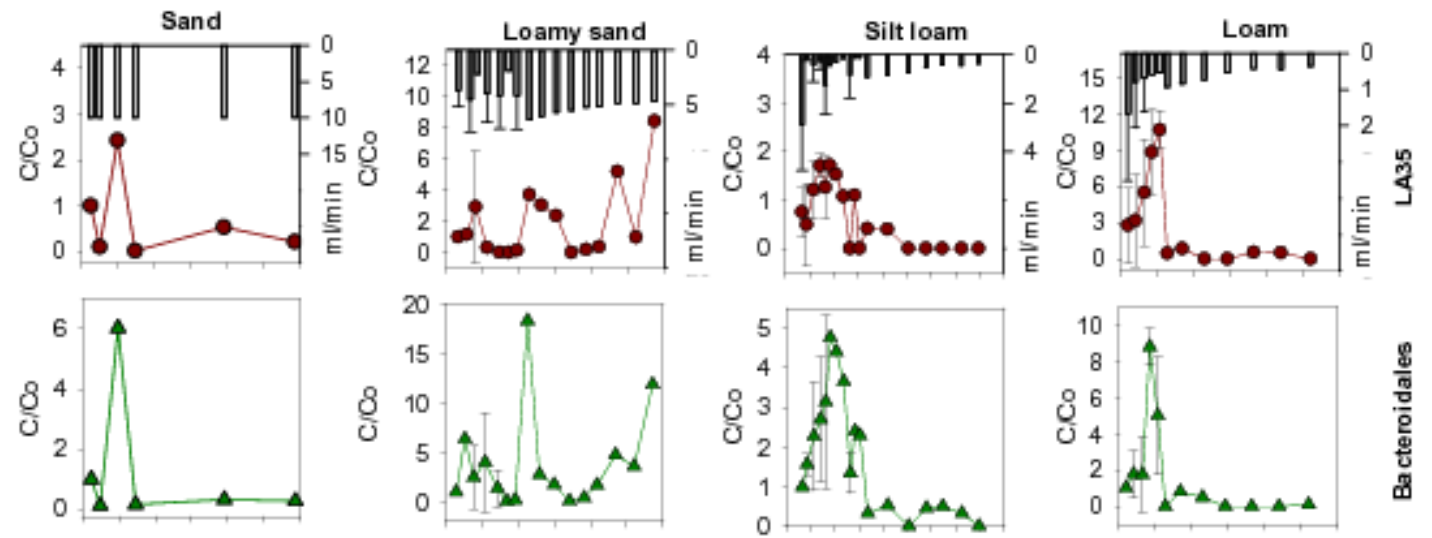

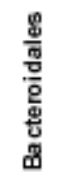
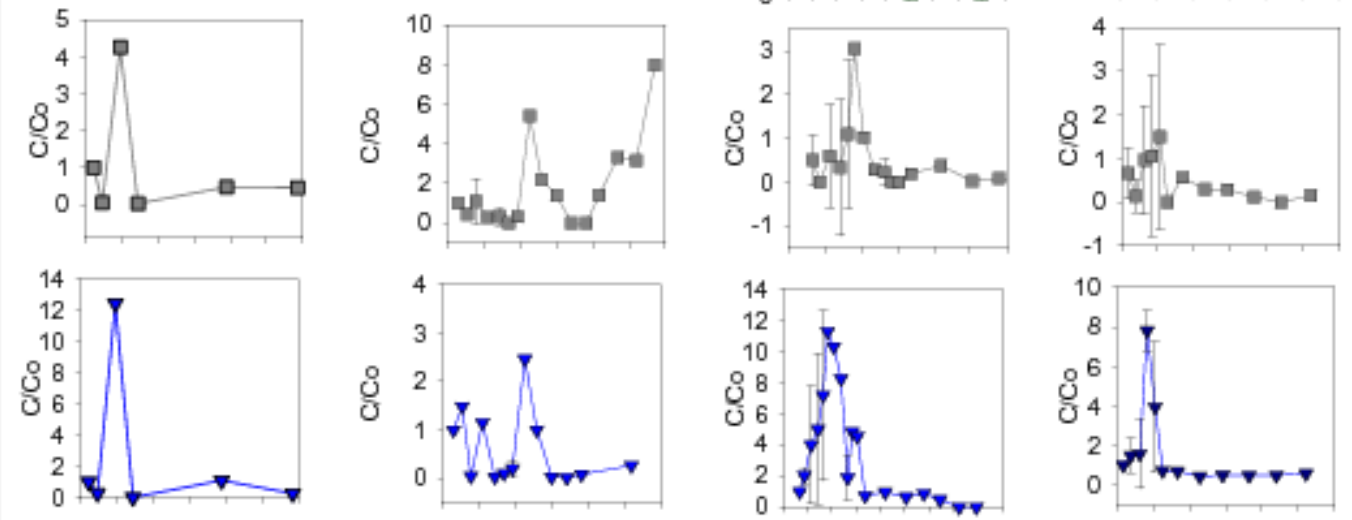

홍
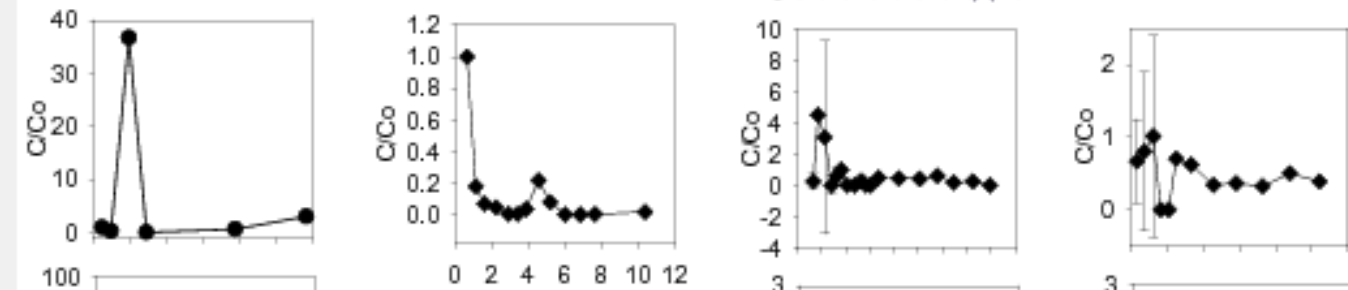

ํㅡㅁ
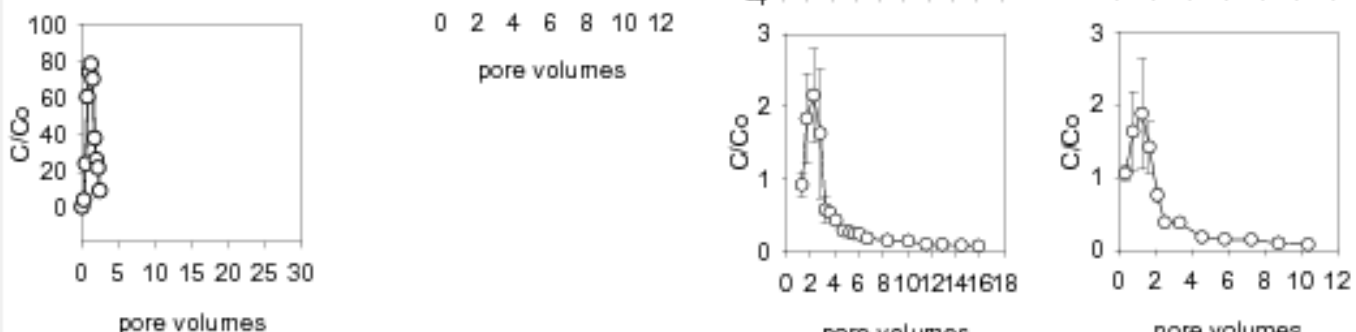

pore volumes

pore volumes 
Figure 2
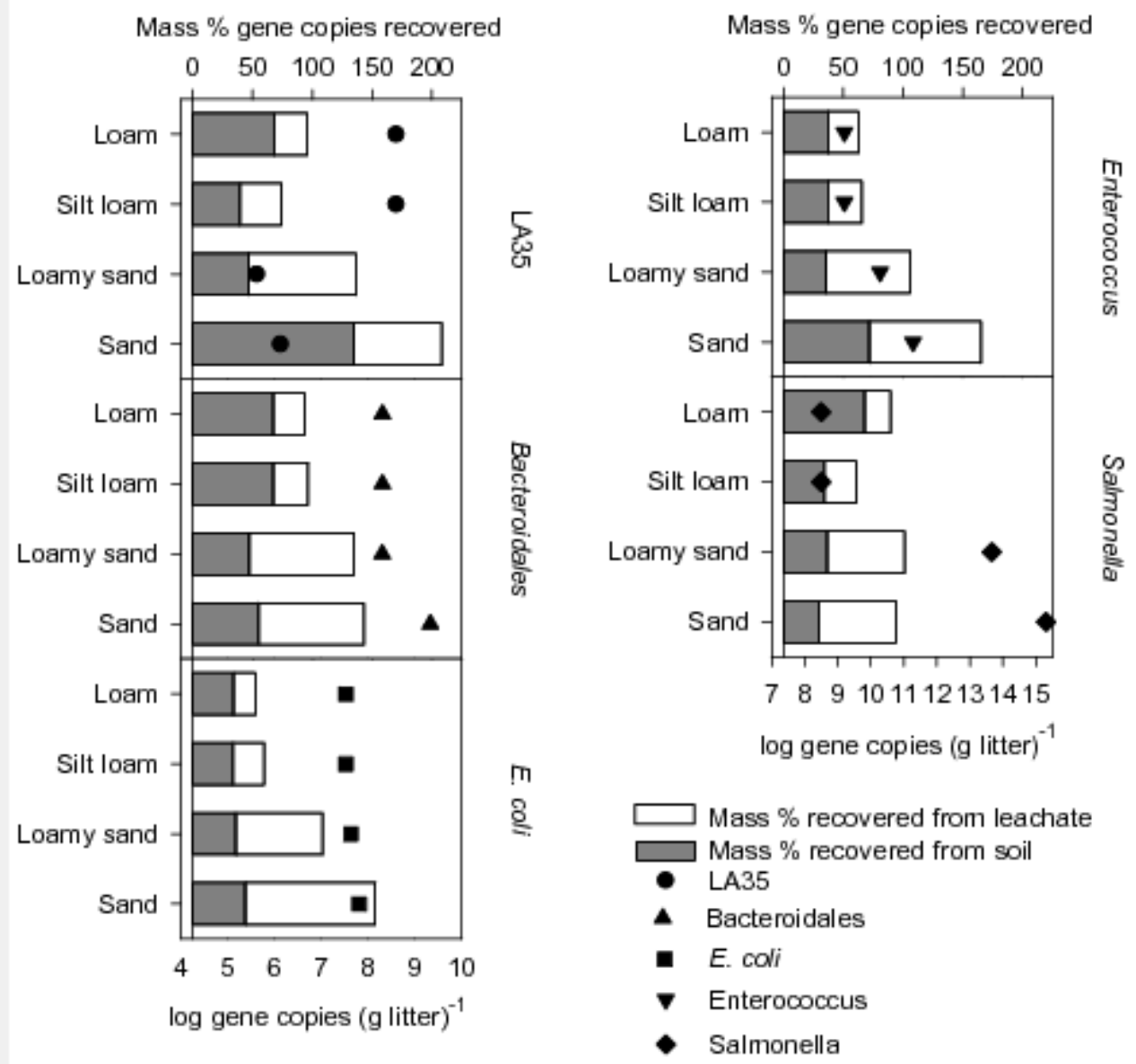


\section{Figure 3}
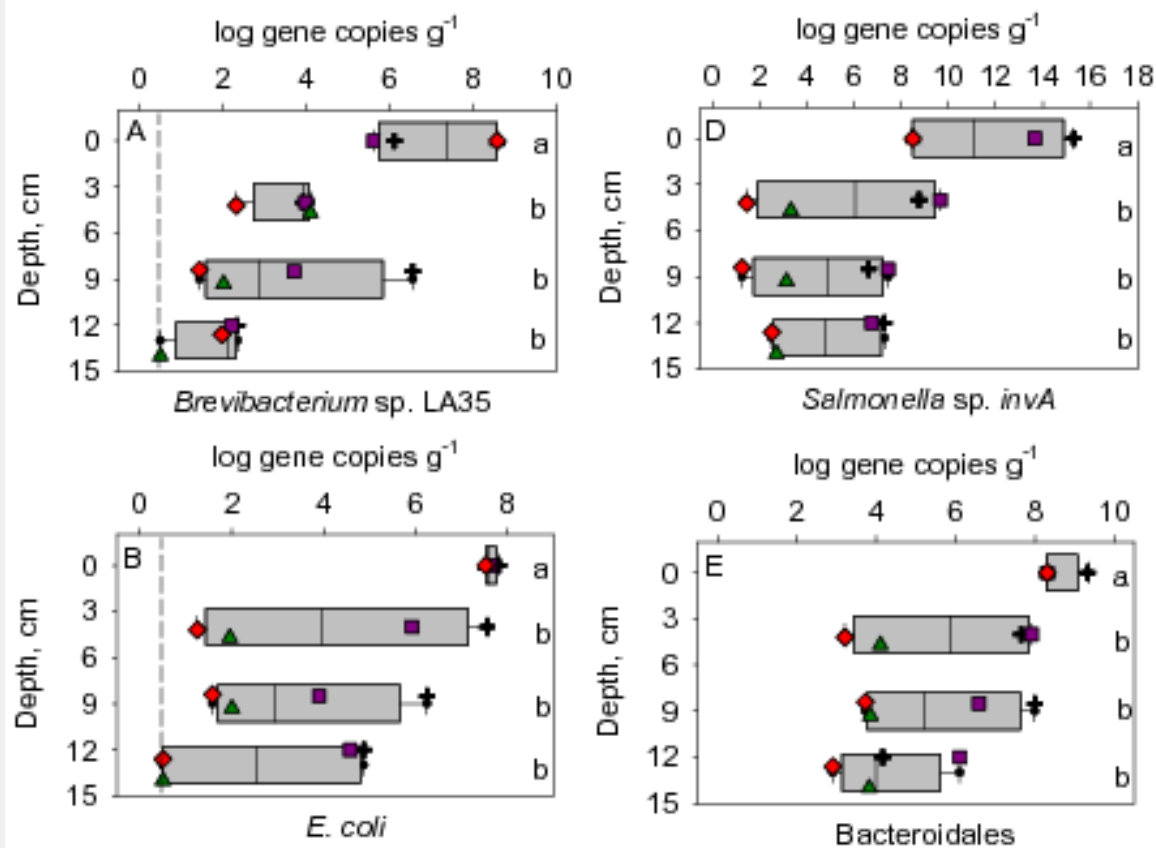

log gene copies $\mathrm{g}^{-1}$

log gene copies $\mathrm{g}^{-1}$
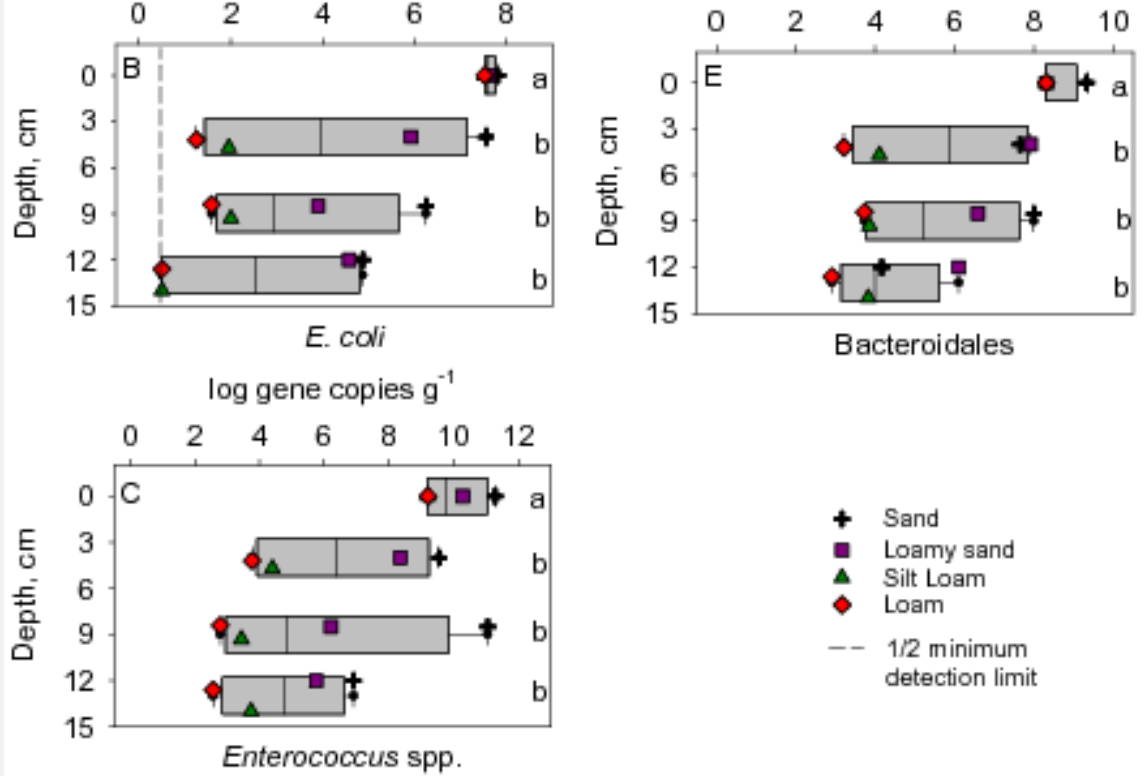

Bacteroidales

+ Sand

- Loamy sand

A Silt Loam

- Loam

-- $1 / 2$ minimum detection limit

Enterococcus spp. 
Table 1. Soil and column properties of the differing soil types used during this study.

\begin{tabular}{|c|c|c|c|c|c|c|c|c|c|}
\hline & \multicolumn{4}{|c|}{ Soil properties } & \multicolumn{5}{|c|}{ Column properties } \\
\hline Soil type & $\begin{array}{c}\% \\
\text { sand }\end{array}$ & $\begin{array}{l}\% \\
\text { silt }\end{array}$ & $\begin{array}{c}\% \\
\text { clay }\end{array}$ & $\begin{array}{l}\text { Organic } \\
\text { matter } \\
(\%)\end{array}$ & Dimensions ${ }^{a}$ & $\begin{array}{l}\text { Pore } \\
\text { volume } \\
\left(\mathrm{cm}^{3}\right)\end{array}$ & $\begin{array}{l}\text { Column } \\
\text { packed } \\
\text { porosity }\end{array}$ & $\begin{array}{l}\text { Flow rate } \\
\left(\mathrm{mL} \min ^{-1}\right)\end{array}$ & $\begin{array}{c}\text { Total volume of } \\
\text { water passing } \\
(\mathrm{mL})\end{array}$ \\
\hline Sand & 96.8 & \multicolumn{2}{|c|}{$3.2^{\mathrm{c}}$} & 0.01 & $\begin{array}{c}12.8 \mathrm{~cm} \text { (L) } \mathrm{x} \\
2 \mathrm{~cm} \text { (D) }\end{array}$ & 28 & 0.33 & 10 & 1200 \\
\hline $\begin{array}{l}\text { Loamy- } \\
\text { sand }^{\mathrm{d}}\end{array}$ & \multirow{2}{*}{87.8} & \multirow{2}{*}{\multicolumn{2}{|c|}{$12.2^{\mathrm{c}}$}} & \multirow{2}{*}{0.97} & $\begin{array}{c}12.7 \mathrm{~cm}(\mathrm{~L}) \mathrm{x} \\
2 \mathrm{~cm}(\mathrm{D})\end{array}$ & 49 & 0.40 & $2.2 \pm 0.3$ & 218 \\
\hline $\begin{array}{l}\text { Loamy- } \\
\text { sand }^{\mathrm{d}}\end{array}$ & & & & & $\begin{array}{c}13 \mathrm{~cm} \text { (L) } \mathrm{x} \\
\mathrm{cm} \text { (D) }\end{array}$ & 55 & 0.36 & $5.6 \pm 0.7$ & 562 \\
\hline $\operatorname{Silt}_{\mathrm{e}}$ & \multirow{3}{*}{23.5} & \multirow{3}{*}{58.6} & \multirow{3}{*}{17.9} & \multirow{3}{*}{5.5} & \multirow{3}{*}{$\begin{array}{c}13 \mathrm{~cm} \text { (L) } x 2 \\
\mathrm{~cm} \text { (D) }\end{array}$} & 25 & 0.63 & $1.2 \pm 1.1$ & 404 \\
\hline $\begin{array}{l}\text { Silt loam } \\
\text { e }\end{array}$ & & & & & & 42 & 0.38 & $0.78 \pm 1.3$ & 183 \\
\hline $\begin{array}{l}\text { Silt loam } \\
\text { e }\end{array}$ & & & & & & 46 & 0.43 & $0.46 \pm 1.1$ & 86 \\
\hline Loam $^{f}$ & \multirow{3}{*}{36.5} & \multirow{3}{*}{46.4} & \multirow{3}{*}{17.2} & \multirow{3}{*}{9.2} & \multirow{3}{*}{$\begin{array}{c}12.6 \mathrm{~cm} \text { (L) } \mathrm{x} \\
2 \mathrm{~cm} \text { (D) }\end{array}$} & 22 & 0.59 & $0.33 \pm 0.19$ & 223 \\
\hline Loam $^{f}$ & & & & & & 34 & 0.40 & $0.64 \pm 0.21$ & 97 \\
\hline Loam $^{\mathrm{f}}$ & & & & & & 32 & 0.47 & $0.38 \pm 0.13$ & 57 \\
\hline
\end{tabular}


Table 2. qPCR primers and probes used in this study

\begin{tabular}{|c|c|c|}
\hline Organism & Primer and probe sequences (5' to 3') & Reference \\
\hline \multirow{3}{*}{$\begin{array}{l}\text { Enterococcus } \\
\text { spp. }\end{array}$} & F: GAGAAATTCCAAACGAACTTG & \\
\hline & R: CAGTGCTCTACCTCCATCATT & (Ludwig and \\
\hline & P: TGGTTCTCTCCGAAATAGCTTTAGGGCTA & Schleifer, 2000) \\
\hline \multirow[t]{3}{*}{ Bacteroidales } & F: GGGGTTCTGAGAGGAAGGT & \multirow{3}{*}{$\begin{array}{l}\text { (Dick and Field, } \\
\text { 2004; Siefring et al., } \\
\text { 2008) }\end{array}$} \\
\hline & R: CCGTCATCCTTCACGCTACT & \\
\hline & P: CAATATTCCTCACTGCTGCCTCCCGTA & \\
\hline \multirow[t]{2}{*}{ E. coli } & F: GTCCAAAGCGGCGATTTG & \multirow{3}{*}{ (Lee et al., 2006) } \\
\hline & R: CAGGCCAGAAGTTCTTTTTCCA & \\
\hline \multirow{3}{*}{$\begin{array}{l}\text { Salmonella } \\
\text { spp. }\end{array}$} & & \\
\hline & F: CGTTTCCTGCGGTACTGTTAATT & \multirow[b]{2}{*}{ (Lee et al., 2006) } \\
\hline & $\begin{array}{l}\text { R: AGACGGCTGGTACTGATCGATAA } \\
\text { P: CCACGCTCTTTCGTCT }\end{array}$ & \\
\hline \multirow{4}{*}{$\begin{array}{l}\text { Brevibacterium } \\
\text { sp. LA35 }\end{array}$} & & \multirow{4}{*}{$\begin{array}{l}\text { (Weidhaas and } \\
\text { Lipscomb, 2013; } \\
\text { Weidhaas et al., } \\
\text { 2010) }\end{array}$} \\
\hline & F: ACCGGATACGACCATCTGC & \\
\hline & R: TCCCCAGTGTCAGTCACAGC & \\
\hline & P: CAGCAGGGAAGAAGCCTTCGGGTGACGGTA & \\
\hline
\end{tabular}


Table 3. Within-column relationships of microbial transport with leachate: Pearson's correlation of normalized ${ }^{\text {a }}$ gene abundance of the various microorganisms in leachate from soil columns in each pore volume sampled. Sand and silt loam with white background; loam sand and loam with gray background)

\begin{tabular}{|c|c|c|c|c|c|c|}
\hline & & LA35 & E. coli & $\mathrm{BAC}$ & ENT & SAL \\
\hline & & & & Sand & & \\
\hline LA35 ${ }^{b}$ & \multirow{5}{*}{ 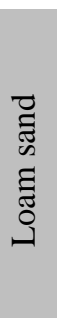 } & & $0.95^{* * \mathrm{c}}$ & $0.82 * *$ & $0.97 * * *$ & $0.84 * *$ \\
\hline E. coli & & $0.80^{* * * *}$ & & $0.90 * *$ & $0.90 * *$ & $0.91 * *$ \\
\hline $\mathrm{BAC}^{\mathrm{b}}$ & & $0.72 * *$ & $0.65 * *$ & & $0.82 * *$ & $0.85 * *$ \\
\hline $\mathrm{ENT}^{\mathrm{b}}$ & & $0.66 * *$ & $0.58 * *$ & $0.62 * *$ & & $0.86 * *$ \\
\hline \multirow[t]{2}{*}{$\mathrm{SAL}^{\mathrm{b}}$} & & $\mathrm{NS}^{\mathrm{d}}$ & $0.50 *$ & NS & $0.67 * *$ & \\
\hline & & & & Silt Loam & & \\
\hline LA35 & \multirow{5}{*}{ 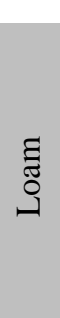 } & & $0.46 * *$ & 0.69 *** & $0.62 * * *$ & NS \\
\hline E. coli & & $0.42 * *$ & & $0.62^{* * *}$ & $0.66^{* * *}$ & NS \\
\hline $\mathrm{BAC}$ & & $0.69 * * *$ & NS & & $0.98 * * *$ & NS \\
\hline ENT & & $0.63 * * *$ & NS & $0.98 * * *$ & & NS \\
\hline SAL & & NS & NS & NS & NS & \\
\hline \multicolumn{7}{|c|}{$\begin{array}{l}{ }^{\mathrm{a}} \text { gene abundance in leachate were normalized by dividing the gene abundance } \cdot \mathrm{mL}^{-1} \text { in any } \\
\text { pore volume by the gene abundance } \cdot \mathrm{mL}^{-1} \text { observed in the first sample collected. } \\
{ }^{\mathrm{b}} \text { LA35= Brevibacterium sp. LA35, BAC }=\text { Bacteroidales, ENT }=\text { Enterococcus } \mathrm{spp} . \mathrm{SAL}=\end{array}$} \\
\hline \multicolumn{7}{|c|}{ Salmonella sp. } \\
\hline \multicolumn{7}{|c|}{${ }^{\mathrm{c}}$ Correlation is significant at the $* * * P<0.001$, $* * P<0.05$, and $* P<0.1$ level } \\
\hline \multicolumn{7}{|c|}{${ }^{\mathrm{d}} \mathrm{NS}=$ not statistically significant } \\
\hline
\end{tabular}


Table 4. Within-column relationships of microbial abundance with depth in soils: Pearson's correlation of log microbial gene abundance of the various microorganisms attached to soil columns over all depths sampled. Sand and silt loam with white background; loam sand and loam with gray background.

\begin{tabular}{|c|c|c|c|c|c|c|}
\hline & & LA35 & E. coli & BAC & ENT & SAL \\
\hline & & & & Sand (A) & & \\
\hline LA35 ${ }^{\mathrm{a}}$ & \multirow{5}{*}{ 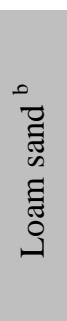 } & & $\mathrm{NS}^{\mathrm{d}}$ & NS & $0.96^{* * \mathrm{c}}$ & NS \\
\hline E. coli & & NS & & $0.89 *$ & NS & NS \\
\hline $\mathrm{BAC}^{\mathrm{a}}$ & & $0.90 *^{\mathrm{c}}$ & $0.90^{*}$ & & $0.97 * *$ & NS \\
\hline $\mathrm{ENT}^{\mathrm{a}}$ & & $0.92 *$ & $0.97 * *$ & $0.97 * *$ & & NS \\
\hline \multirow[t]{2}{*}{$\mathrm{SAL}^{\mathrm{a}}$} & & $0.94 *$ & $0.96 * *$ & $0.92 *$ & $0.99 * *$ & \\
\hline & & & & Silt Loam & & \\
\hline LA35 & \multirow{5}{*}{ 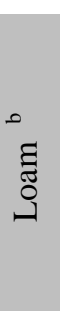 } & & $0.96 * *$ & $0.93 *$ & $0.94 *$ & $0.94 *$ \\
\hline E. coli & & $0.98 * *$ & & $0.98 * *$ & $0.97 * *$ & $0.99 * *$ \\
\hline BAC & & $0.96^{* *}$ & $0.99 * * *$ & & $0.99 * *$ & $0.99 * *$ \\
\hline ENT & & $0.99 * *$ & $0.99 * *$ & $0.98 * *$ & & $0.99 * *$ \\
\hline SAL & & $0.99 * *$ & $0.96^{* *}$ & $0.96 * *$ & $0.96 * *$ & \\
\hline \multicolumn{7}{|c|}{${ }^{a}$ LA35 $=$ Brevib } \\
\hline \multicolumn{7}{|c|}{ Salmonella sp. } \\
\hline \multicolumn{7}{|c|}{$\begin{array}{l}\text { b Gene abundance in soils of replicate soil columns were averaged with depth prior to correlation } \\
\text { analysis }\end{array}$} \\
\hline \multicolumn{7}{|c|}{${ }^{\mathrm{c}}$ Correlation is significant at the $* * * P<0.001, * * P<0.05$, and $* P<0.1$ level } \\
\hline \multicolumn{7}{|c|}{${ }^{\mathrm{d}} \mathrm{NS}=$ not statistically significant } \\
\hline
\end{tabular}




\section{Graphical Abstract}

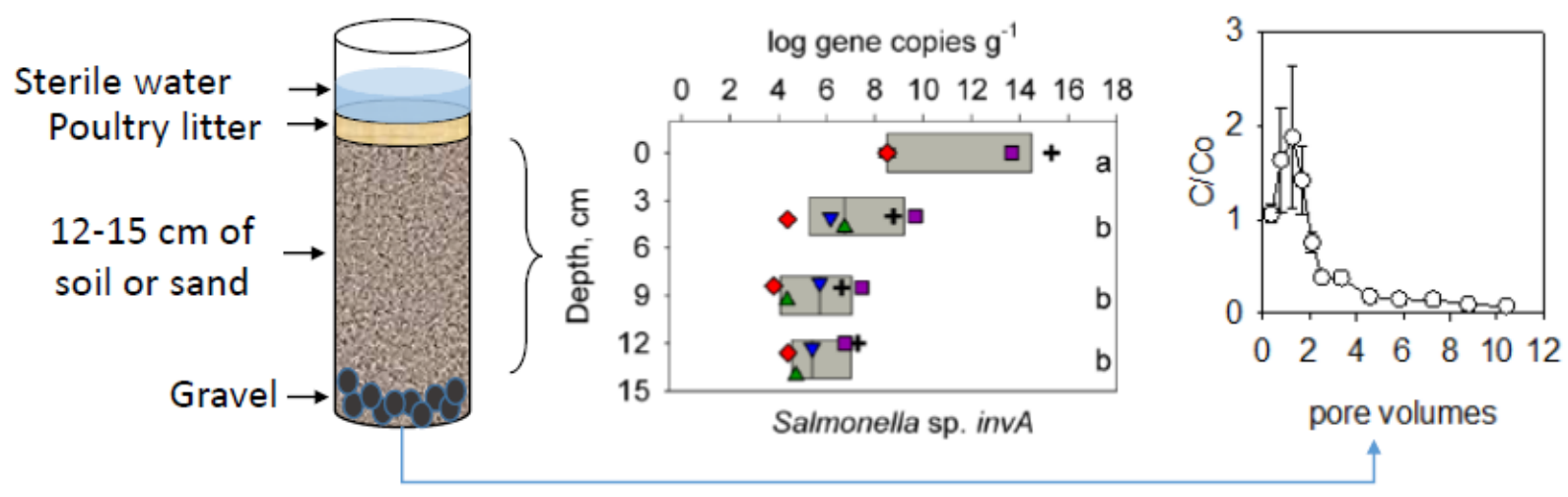

